\title{
A demonização em A Conquista Espiritual (1639), de Antonio Ruiz de Montoya e na Festa de S. Lourenço (1587), de José de Anchieta
}

\author{
Silvio Ruiz Paradiso
}

\section{SciELO Books / SciELO Livros / SciELO Libros}

PARADISO, SR. A demonização em A Conquista Espiritual (1639), de Antonio Ruiz de Montoya e na Festa de S. Lourenço (1587), de José de Anchieta. In MAGALHÃES, ACM., et al., orgs. $O$ demoníaco na literatura [online]. Campina Grande: EDUEPB, 2012. pp. 199-214. ISBN 978-857879-188-9. Available from SciELO Books <http://books.scielo.org $>$.

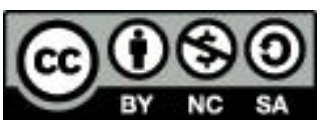

All the contents of this work, except where otherwise noted, is licensed under a Creative Commons Attribution-Non Commercial-ShareAlike 3.0 Unported.

Todo o conteúdo deste trabalho, exceto quando houver ressalva, é publicado sob a licença Creative Commons Atribuição Uso Não Comercial - Partilha nos Mesmos Termos 3.0 Não adaptada.

Todo el contenido de esta obra, excepto donde se indique lo contrario, está bajo licencia de la licencia Creative Commons Reconocimento-NoComercial-CompartirIgual 3.0 Unported. 


\section{A demonização em A Conquista Espiritual (1639), de Antonio Ruiz de Montoya e na Festa de S. Lourenço (1587), de José de Anchieta}

Silvio Ruiz Paradiso (PG- UEL Capes/UEM) ${ }^{1}$

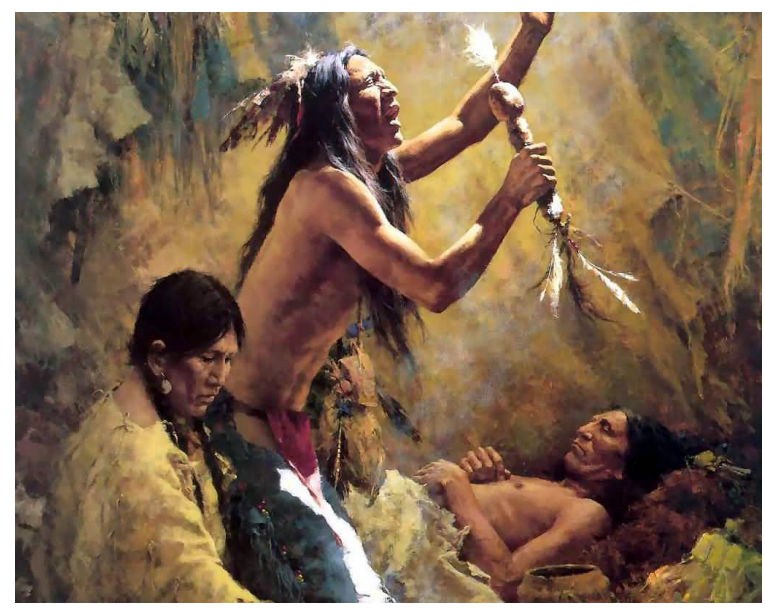

O cristianismo está intimamente ligado à expansão ultramarina e à colonização da América. A crença na supremacia europeia se baseava também na supremacia da religião cristã, afinal, para portugueses, ingleses e espanhóis, a colonização era, também, a expansão da única e verdadeira fé. Nesse sentido, Deus não apenas abençoava, mas tornava possível a expansão colonial. A missão religiosa foi um dos elementos mais importantes nos processos colonizatórios entre os séculos $X V$ e XX por todo mundo, em especial, no projeto colonial português e espanhol, com o padroado, por exemplo.

1 Doutorando pela Universidade Estadual de Londrina (UEL) em Estudos Literários/ Diálogos Culturais. Bolsista CAPES. Graduado em Letras Anglo-portuguesas pelo Centro Universitário de Maringá. E-mail: silvinhoparadiso@hotmail.com 
Embora não tenha sido o único aspecto importante, o processo de conversão foi fator decisivo para conquistas territoriais ou estratégias políticas. Em muitos casos, os missionários estavam entre os primeiros 'desbravadores' mandados às colonias. Sua ação ao conquistar corações e mentes, abria caminho para os demais conquistadores. Tal caminho, iluminado pela Sagrada Escritura, tinha êxito devido à conversão de chefes e reis das então 'novas' terras, resultando, por consequência, a conversão dos súditos e de toda a comunidade autóctone ali representada.

Pregar o cristianismo, isto é, a prática de prosélytus nasce da frase profética de Jesus no Evangelho de Marcos (16:15-16): "E disse-lhes: Ide por todo o mundo, pregai o evangelho a toda criatura. Quem crer e for batizado será salvo; mas quem não crer será condenado”. Os missionários cristãos se espalharam por todo mundo, subsidiados pelo projeto colonial. Nas caravelas, sacerdotes católicos e protestantes - em menor grau, quando na Ámerica do Norte e Caribe -, armados com Bíblias e com grande eloquência, dirigiam-se às terras imaculadas pela ideologia europeia, levando à frente a sentença predita por Jesus: "quem não crer será condenado". E a condenação não tardou a chegar para muitos ameríndios e africanos, que se recusaram a assimilar a nova religião trazida pelo colonizador.

Uma mentalidade medieval mostrou sua persistência na Península Ibérica e fez com que ideais "cruzadistas" estivessem presentes nos grandes empreendimentos marítimos. Por essa razão, a conquista da América está relacionada com dois signos da civilização cristã europeia: a cruz e a espada.

A palavra conversão vem do latim conversio, traduzindo o grego metanoia, que significa literalmente "ir sentido oposto" ou "mudar a mente". A conversão religiosa seria, basicamente, a adoção de uma nova religião que difere da anterior do converso. Pessoas se convertem a uma religião diferente por várias razões, incluindo: a conversão ativa por livre escolha, devido a uma mudança nas suas crenças pessoais; a conversão secundária; conversão no leito de morte; a conversão de conveniência e de conversão civil e conversão forçada.

A Igreja considera que a conversão exige internalização do novo sistema de crença, implicando um novo ponto de referência: a autoidentidade do converso. Isso implica em assimilação completa (língua, mitos, estrutura, hierarquia, ritos) da nova religião e recusa da antiga. Entretanto, Machado (1994) aponta que "em situações de desorganizações de 
esquemas culturais de interpretação", isto é, os choques culturais, que acontecem frequentemente nos ambientes coloniais, a conversão não é feliz nessa reinterpretação hegemônica da sociedade autóctone. Neste contexto falho de reinterpretação, repleto de lacunas e conflitos identitários, o fenômeno da conversão e catequese podem não apresentar o sucesso pretendido, gerando exclusões, conflitos, desestruturas sociais e em especial a demonização.

A demonização é fruto, quase sempre da alteridade e da não aceitação e da nova fé e é imposta. No caso da colonização portuguesa da América, os grandes protagonistas desse processo de rejeição são os pajés e os índios inimigos das reduções aliadas, isto é, o outro demoníaco.

No presente artigo, analisar-se-á a demonização dos nativos analisados sob a perspectiva pós-colonial em duas narrativas: A Conquista espiritual (1639) do missionário peruano Antonio Ruiz de Montoya, e Na festa de S. Lourenço (1587), do jesuíta José de Anchieta.

\section{Conversão em $A$ conquista espiritual (1639), de Antônio Ruiz de Montoya}

Em 1585, em Lima, no Peru, nascia Antonio Ruiz de Montoya, um padre jesuíta que escreveria a primeira gramática escrita da Língua Guarani - o Tesoro de la lengua guaraní, publicado em 1639 em Madri, na Espanha. Entrou na Companhia de Jesus em $1^{\circ}$ de novembro de 1606, e no mesmo ano, acompanhou o Padre Diego Torres, o primeiro provincial do Paraguai, para tal missão.

Junto com os padres Cataldino e Mazeta, o peruano fundou as reduções de Guairá, trazendo uma série de tribos silvícolas para os seios da Igreja Católica, e afirma ter batizado pessoalmente mais de cem mil índios. Como chefe das missões, Montoya tinha a encargo de 1620 a "redução" no curso superior e médio do rio Paraná e do rio Uruguai, acrescentando mais treze "reduções" para as 26 já existentes. Quando as missões de Guairá foram ameaçadas pelas incursões dos paulistas do Brasil em busca de escravos, os padres Mazeta e Montoya resolveram transportar os índios 'convertidos' (um total de 15 mil), por água se deu com a ajuda de 700 balsas e canoas, mostrando sua convicção na empreitada. 
Montoya em 1637 (em nome do governador, do Bispo do Paraguai e dos chefes das ordens) apresentou uma reclamação formal a Filipe IV da Espanha, sobre a política portuguesa de envio de expedições às regiões vizinhas, na América espanhola. Montoya também foi o padre jesuíta encarregado de se queixar diretamente ao rei de Portugal, sobre os bandeirantes paulistas que atacavam as missões jesuítas em busca de índios para serem vendidos. Toda sua catequese foi escrita por ele mesmo, em a Conquista Espiritual. Enquanto escrevia, vivia no Paraguai, onde outros jesuítas mantinham inconteste a jurisdição sobre os indígenas no Vice-Reinado do Peru. Após o retorno à América, Montoya faleceu em 1652.

\section{Montoya e os pajés/caciques Neçu, Taubici, Guirabera, Maracanã e Artiguaye}

A divisão maniqueísta que se formava entre toda população das margens dos rios Paraná, Uruguai e do rio Tape era inegável. O fato se dava na clara divisão: bem e mal, fomentada pelos jesuítas, cujas legiões dessa guerra se formavam entre o clero e os índios convertidos contra pajés e xamãs e os índios rebeldes, liderados por Jesus e pelo diabo respectivamente.

A Igreja Católica espanhola entrou em território sul-americano, junto com os demais colonizadores espanhóis, encabeçados pelo conquistador Pedro de Medonza y Luján, em 1535, na região da Prata. Lozano (1912) observa que com a Igreja fixada, anos depois, o bispo de Tucumán, Francisco de Victoria, convida a Cia. de Jesus a fazer parte da região, apesar desta já possuir algumas reduções controladas pelos franciscanos (VIEIRA \& SOUZA, 2004, p.3). Os missionários chegam ao Paraguai e Peru entre 1587-1588, encontrando uma gigantesca mãe-natureza, a qual abrigava duzentos mil índios guaranis - um local muito propício para a catequese dos então "selvagens" do Novo Mundo.

O catecismo guarani, utilizado em toda a província, foi elaborado pelo frei Luis de Bolaños e oficializado em 1603 pelo Sínodo de Assunção (VIEIRA \& SOUZA, 2004, p.3). Bolaños havia escrito um dicionário e uma gramática do guarani, facilitando em muito o êxito da evangelização 
entre tribos da região. O jesuíta Antônio Ruiz de Montoya possuía uma definição própria para as reduções, locais com "diligencia de los padres a poblaciones grandes y a vida política y humana, a beneficiar algodón con que se vistan" (MONTOYA, 1892, p.29), isto é, para Montoya, as reduções não só cristianizaria os índios, mas os "civilizariam".

Em 1604, com as bênçãos do Padre Aquaviva geral da Companhia de Jesus, em Roma, e o aval de Felipe III, formou-se a província jesuítica do Paraguai. Montoya, todavia, iria chegar a Guairá oito anos depois, em 1612. Antonio Ruiz de Montoya iria descrever suas ações e narrar todos os acontecimentos em Guairá, no seu texto Conquista Espiritual hecha por los religiosos de la Compañia de Jesús, en las Provincias del Paraguay, Paraná, Uruguay y Tape (1639). No texto, focamos nos obstáculos dessa conquista espiritual dos jesuítas: os caciques e pajés.

Para os espanhóis, caciques e pajés eram sinônimos. Esse reducionismo se baseava na ideia de denominação dos chefes indígenas americanos, difundida por portugueses e espanhóis. Cacique vem do arauaque (Haiti) cachique, "chefe político", castelhanado cacique. Para os guaranis, a denominação empregada para seus principais é mburovixá. Já o pajé é um termo tupi referente a uma pessoa de destaque, portadora de poderes ocultos ou orientadores espirituais. Segundo o dicionário: "chefe espiritual dos índios, misto de feiticeiro e médico” (LUFT, 2001, p.497).

Com uma enorme cruz fincada no centro da redução, o território para a guerra espiritual estava preparado - pajés e jesuítas conviviam na mesma zona de contato, outremizando ${ }^{2}$ um ao outro, afinal, os pajés contestavam o poder dos clérigos, acreditando serem eles destruidores de uma cultura religiosa ancestral, enquanto para os jesuítas, esses, que insistiam em não se converter eram (na concepção colonial) seres sem alma, trabalhadores do demônio, a fim de atrapalhar os planos da salvação daquela gente - a guerra estava formada.

2 Transformar em outro. O conceito de outremização foi cunhado por Gayatri Spivak (1985) e descreve o processo de "transformar" o sujeito colonial em outro, a partir dos pressupostos de superioridade do sujeito metropolitano. A outremização é particularmente muito próxima da objetificação, já que, segundo Spivak (apud Ashcroft et al.) a criação de outros, nada mais é que a criação de pequenos objetos do/para o imperialismo , no qual o indivíduo outremizado perde sua agência e sua subjetividade (PARADISO, BONNICI, 2012). 
A dialética nas reduções baseava-se na divisão dos índios em convertidos e não convertidos. Os grupos, em constante confronto, representavam, como o próprio Ruiz de Montoya refere-se, a imagem do Juízo Final: "uma representação do Juízo Final, como em geral se pinta. Assim, figurava ela [a redução] e os Anjos defendendo as almas, e os demônios atacando-as. Enxergou que faziam o papel de Anjos os da Companhia" (MONTOYA, 1985, p.30).

Aqueles que se recusavam se curvar perante a fé cristã eram constantemente demonizados e objetificados, a fim de garantir aos índios convertidos que estes fizeram a escolha pelo bem.

Encabeçando os rebeldes, estavam os líderes religiosos indígenas, os pajés e caciques, empenhados em desmoralizar os padres e a doutrina cristã. Os pajés eram outremizados pelos religiosos, recebendo adjetivos variados como: miserável, familiar ao diabo, feiticeiros, magos, fingidos, entre outros. Por não estarem convertidos ao propósito da fé católica, se armavam com estratégias como paródia e mímica (BHABHA, 1998), o revide e a subjetificação.

Dentre os "caciques", o mais problemático aos olhos da conquista espiritual, era Taubici, que segundo Montoya, significava "diabos em fila ou fileira de demônios [...]" (MONTOYA, 1985, p.48), um claro exemplo de demonização deste por parte do padre peruano.

O pajé ${ }^{3}$, mesmo salvando a vida dos inacianos, já era considerado como um indivíduo 'mau':

Esse homem recebeu-nos bem e, embora mau, livrou-nos da morte, porque naquela noite de nossa chegada alguns índios queriam matar-nos e, ainda que estivessem dispostos a fazê-lo, pareceu-lhes que não o deviam sem consulta sua. A isso respondeulhes ele: 'Se vós quiserdes matar os padres, fazei-o, mas eu não vou meter-me nisso!' Este desdém bastou para que não nos tirassem a vida, quando a esse respeito confabulavam,... (MONTOYA, 1997: 51. Grifo meu).

3 Alguns como Taubici eram caciques e pajés simultaneamente. 
As estratégias de Taubici eram variadas, já que contestava a liderança dos padres. Uma delas era o vaticínio mediante os transes que, quando confirmados, aumentava seu prestígio e confiança dentro da comunidade guarani. Uma das mais famosas profecias de Taubici foi sobre as consequências do furto de cana-de açucar por alguns índios; Taubici vaticinou aos reclamantes do furto, que os que roubaram seriam castigados "pela enfermidade de câmeras", isto é, diarreia. O próprio Montoya confirma a realização do fato pouco tempo depois (MONTOYA, 1997: 52). Entretanto, argumentava que os poderes de Taubici eram oriundos de sua fraternidade com o demônio: "[...] Ordenava descobrir alguma parte do telhado de sua casa, e era lá por onde houvesse de entrar o mau espírito. Sobrevinham então a esse miserável determinados desmaios, e as mulheres o ajudavam, segurando-lhe os braços e a cabeça, ao passo que ele fazia trejeitos e meneios ferozes" (MONTOYA, 1985, pp. 48-49).

Montoya percebeu o apego dos índios guaranis às visões, transes e premonições, fazendo discursos para a conversão, alertas para esses embustes diabólicos; até porque, o transe, o vaticínio e a possessão tornam-se armas políticas na boca do colonizado (PARADISO, 2011). O que não critica, porém, são os mesmos fenômenos vindos de sua gente, os cristãos, que também podiam ter seus sonhos premonitórios:

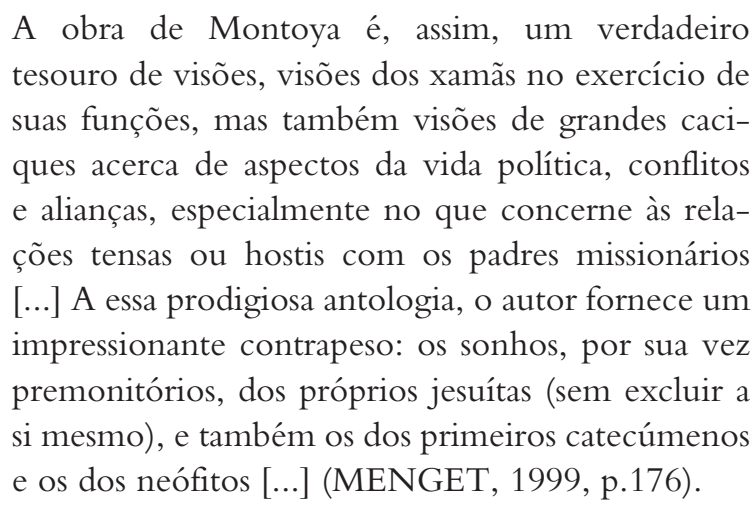

As visões dos não conversos deveriam ser repudiadas e demonizadas, para que as visões dos cristãos pudessem ser exaltadas. A coroação da sacralidade das visões cristãs veio com o "acerto" de uma profecia ocorrida em favor dos padres, no dia de Corpus Christi, em que Taubici decidiu convocar alguns índios para o encontro com outros não-conversos, ignorando a missa e a procissão do dia. O fato desencadeou a 
advertência do jesuíta Masseta, que os dissidentes iriam ser castigados pela falta. Aconteceu que, por coincidência, o grupo fora atacado por índios rivais, sedentos de vingança contra Taubici, que assassinara um membro daquele grupo tempos atrás. Era o fim do pajé (MONTOYA, 1997, p.52).

Outra pedra nos sapatos dos sacerdotes era Neçu, "o maior dos caciques que aqueles 'países' conheceram” (MONTOYA, 1997, p.223). Além disso, era caracterizado por suas "artimanhas, embustes e magias, com as quais enganava aquela gente bárbara” [...] consequência do furor em que o demônio ardia (MONTOYA, 1997, p.223). A conquista Espiritual narra uma das estratégias de $\mathrm{Neçu} \mathrm{-} \mathrm{a} \mathrm{fim} \mathrm{de} \mathrm{arrebanhar} \mathrm{os}$ índios já convertidos - usava os "paramentos litúrgicos" sacerdotais para se assemelhar aos jesuítas: "Neçu, de sua parte e para mostrar-se sacerdote, conquanto falso, revestiu-se dos parâmetros litúrgicos [...]. E fez trazer em sua presença as crianças, nas quais tratou de apagar com cerimônias bárbaras o caráter indelével, que elas pelo batismo tinham impresso em suas almas [...]" (MONTOYA, 1997, p.228). Neçu se apropriava das ideias ritualísticas católicas, subvertendo-as, afinal, sabendo dos ritos cristãos, usava o inverso para anulá-los; enquanto os religiosos focavam no batismo, Neçu incentivava o "desbatismo", lavando os recém-batizados dos pés à cabeça (no sentido inverso da queda d'água cristã), raspava a língua das crianças que "haviam saboreado o sal do espírito sapiencial", e as costas dos que foram ungidos por santos óleos (FAUSTO, 2005, s/p).

Todavia, quem outrora era demonizado, a partir da conversão passa a se tornar exemplos, homens virtuosos e mártires. O cacique e pajé Guirabera, por exemplo, antes chamado mago e canibal, que ardia em furor e desejo a devorar o padre Montoya (MONTOYA, 1997, p.137) e que parodiava missas no meio da mata, substituindo hóstia e o vinho, por bolo de mandioca e vinho de milho, se rendia à verdade cristã. Montoya ao usar o adjetivo "grande" ante ao termo feiticeiro", antecipava a conversão e o êxito de recuperação deste.

O sucesso de conversão também se deu ao cacique Tambavê, que "tão grande foi sua eficácia em pregar a Cristo que, transformado em Paulo, contribui na conversão de muitos gentis" (MONTOYA, 1997, p.231) ou a Roque Maracanã, "un honrado cacique, deseoso de oír las cosas de su salvación” (MONTOYA, 1892, p.47), que agora catequizado, isto é, 
no "lado bom" fora perdoado por ter assassinado um mago no rio, com uma pedra amarrada no pescoço. $\mathrm{O}$ assassinato de um ímpio pelas mãos de um índio cristianizado era visto não como "crime", mas como uma punição de Deus aos infiéis.

Contudo, alguns casos de conversão culminavam com o fracasso, como Miguel Artiguaye (Miguel, devido à conversão) que se apropria do termo "demônio" e de ideias cristã (imortalidade d'alma) para revidar o discurso dos jesuítas. Artiguaye chama os padres de demônios, que destroem a cultura ancestral (MONTOYA: 1892, 57), além de ironizar as ameaças dos padres com a frase: "no me matareis el alma por ser imortal" (MONTOYA, 1997: 235).

Assim, Artiguaye, Taubici, Neçu, Guirabera, Maracanã e Tambavê são exemplos dos resultados múltiplos da conversão no texto $A$ conquista Espiritual, de Antonio Ruiz de Montoya, um fenômeno que dividiu a América do Sul em paraíso e inferno, com seus respectivos habitantes.

\section{Demonização em Na Festa de São Lourenço, de José de Anchieta (1587)}

Cognominado de Apóstolo do Brasil, José de Anchieta foi um sacerdote jesuíta espanhol, nascido em San Cristóbal de la Laguna, nas Canarias, no dia 19 de março de 1534. Até 1548 viveu com a família, que abandonara para poder estudar Filosofia no Real Colégio das Artes e Humanidades, em Coimbra. Sua ida a Portugal foi consequência de sua ascendência judaica, uma vez que em Espanha, a Inquisição era muito mais rigorosa. Em 1551 decide entrar na ordem jesuíta como noviço.

Com a necessidade de atividades de evangelização no Brasil, o provincial dos Jesuítas na colônia, padre Manuel da Nóbrega, solicitou ao então provincial de todo ordem na época, Simão Rodrigues, uma indicação. Este por sua vez, indicou, entre outros, José de Anchieta, que chegou ao Brasil em 13 de junho de 1553, recebendo a incumbência de administrar e construir o Colégio. Em sua estadia, Anchieta aprendera o tupi, que se somava com os outros três idiomas que dominava: castelhano, latim, e português. O jesuíta além de escrever a primeira gramática desta que, na América Portuguesa, seria chamada de "língua geral", escreveu poemas líricos, cartas sobre filologia e várias peças teatrais. 
Com elenco formado por indígenas e portugueses, o auto Na festa de S. Lourenço ou apenas $O$ auto de São Lourenço, foi representado no átrio da capela do mesmo santo, em 10 de agosto de 1857, em idioma tupi, castelhano e português.

A peça gira em torno do martírio de São Lourenço, queimado por Valeriano, censor do Imperador romano Décio. Literatos modernos a dividiram em 5 atos ou cenas: [1] música de abertura, em castelhano, sobre o martírio do santo; [2] cena em tupi, sobre os três demônio índio controlando a comunidade;[3] demônios-índio punindo os romanos pelo martírio de s. Lourenço, cena em tupi e português; [4] cena com mensagens de personagens alegóricos, como o 'amor de Deus' e o 'temor de Deus', cena em português e castelhano e [5] resolução do conflito dramático, dança e música em tupi. O próprio ato 4 , sintetiza bem com suas alegorias, o binarismo necessário para o entendimento nativo acerca do pecado e absolvição, bem e o mal, inferno e Paraíso e Deus e o diabo.

Estudiosos (MARTINS,1948) consideram o auto de São Lourenço a melhor peça de Anchieta (apud MOUTINHO, 1999, p.196) "Longa sem ser monótona , simpática apesar de sátira, capaz, sem dúvida, do êxito que lhe atribuíram na época, e ainda hoje digna de atenção e interesse".

\section{Santos e demônios na América de Anchieta e dos índios tupis}

A catequese jesuítica se baseou em um plano de colonização comum no mundo colonial: o deslocamento de vários índios em locais menores, as aldeias jesuítas, chamadas posteriormente de reduções. As reduções, nome advindo do termo 'reduzir' sendo "usado para representar a submissão do índio ao cativeiro (BOGONI, 2009: 135), eram estruturas de aldeiamento o qual evitava a dispersão dos índios e do contato com os encomederos e/ou bandeirantes. Para Necker (1979) e Melià (1978), as reduções surgiram como "Projeto político de integração do ameríndio dentro do sistema colonial, transmitindo-lhe o cristianismo e a civilização, fortemente eurocêntricos" (apud BOGONI, 2009: 136). As reduções eram grandes 'palcos' para o teatro cristão. 
Havia uma necessidade de orientar a catequese, segundo os costumes e tradições indígenas. O Padre Manuel Nóbrega sabia das funções didáticas e pedagógicas do teatro, além de sua eficácia para doutrinamento teológico. Desta forma, as origens do teatro brasileiro estão intimamente ligadas ao início da catequese jesuítica, cuja autoria perpassa a Navarro, Nóbrega e principalmente, Anchieta (MOUTINHO, 1999, p.191), que foi incumbido de organizar a dramaturgia nas reduções.

O texto, trilíngue de Anchieta baseava na ideia de que os demônios advogavam pelos terríveis hábitos dos índios: o cauim ${ }^{4}$, o fumo, o curandeirismo e a poligamia, e tais demônios eram nada mais que os próprios índios que, todavia, não aceitavam a proposta civilizadora e messiânica dos portugueses cristãos. O demoníaco em Guiaxará, principal de Cabo Frio, é caracterizado a partir da sua não aceitação dos costumes europeus, isto é, costumes cristãos: "Esta virtude estrangeira/Me irrita sobremaneira./ Quem a teria trazido,/com seus hábitos polidos/estragando a terra inteira?" (ANCHIETA, 2012, p.4. Grifo meu).

Essas virtudes e hábitos trazidos pelos jesuítas visavam, segundo a crença dos religiosos, 'civilizar' os índios, destituindo-os de uma imagem tida como bestial, imagem essa oriunda da mentalidade colonial europeia frente aos povos de outras terras. Os índios-demônios são moldados a partir do estereótipo do homem-besta de Aristóteles, em Política, 1254 ab. (apud BONNICI, 2000, p.62), e recriados sob os resquícios dos monstros medievais e das bestas do Novo-Mundo.

Em contrapartida, a imagem idealizada apresentada pelo Anjo e pelos mártires cria a polarização entre o bem (civilizados) e o mal (selvagens).

A demonização é uma estratégia de corrigir hábitos autóctones que, de acordo com a mentalidade religiosa de Anchieta só cabia ao demônio, o deus estrangeiro5: "bebemos dias inteiros./Adornaram-se festeiros./Me abraçaram, me hospedaram,/das leis de deus estrangeiro" (ANCHIETA, 2012, p.7).

4 Cauym ou Cauim é uma bebida alcoólica tradicional dos indígenas brasileiros, feita através da fermentação da mandioca ou do milho.

5 Devemos entender que o discurso de Aimberê é escrito por Anchieta. Logo, o deus estrangeiro a quem o índio-diabo se refere não é o Deus cristão, mas sim o demônio, que habita outras tribos e não mais entre os tupis, agora acolhidos pelo cristianismo. 
Desta forma, apesar dos diabos não serem caracterizados fisicamente (com exceção de sabermos que possuem chifres, garras e tridentes [ANCHIETA, 2012, p.23], ou seja, uma estereotipada imagem do diabo medieval), são caracterizados a partir de um viés cultural, ou seja, a demonização se dá a partir do canibalismo, no excesso, na embriaguês, na dança, na poligamia, etc. (MELLO \& SOUZA, 1993, p.33), como percebemos na fala de Aimberê: "Os jovens que censuravam/ com morubixaba dançam,/ e de comer não se cansam,/ e no cauim se lavam,/ e sobre as moças avançam" (ANCHIETA, 2012, p.20). Esse excesso é a marca recorrente na construção dos demônios-índios: Meu sistema é o bem viver./[...]Boa medida é beber/cauim até vomitar. [...] Beber caium até vomitar,/ ser beberrões, embriagar (ANCHIETA, 2012, II, pp.5 e 6).

O mal é corporificado em três indígenas: Guiaxará, Aimberê e Saravaia, os dois primeiros, nomes de índios conhecidos pelos portugueses na época. Em suas cartas, Anchieta revela que estes índios tamoios lideraram com seus pares um apoio aos franceses contra os portugueses, numa batalha de 1567. Todavia, os portugueses liderados por Mem de Sá e Estácio de Sá venceram com auxílio dos índios temiminós. Já Saraiva ou Saravaia, seria a versão tupi 'criada' por Anchieta para o termo selvagem (BRAGA-PINTO, 2003, p.95). Desta forma, o diabo será corporificado em nativos que representam a não aceitação política e religiosa portuguesa.

Os demônios-índios Guaixairá, Aimberê e Saraiva no início do Ato II, demonstram discursivamente que têm poderes sobre os índios, e descrevem todos os terríveis pecados que eles os submetem. Entretanto, estes pecados são os elementos coesão sócio-cultural indígena (COSTA, 2007, p.108), notadamente as cauinagens e os rituais de antropofagia, sobre os quais se alicerçavam a cosmogonia desse povo. A demonização cultural é clara, quando Aimberê avalia que os rituais vêm de épocas antigas, alcançando velhos, moças e jovens, isto é, que fazem parte da identidade do povo tupi: "Todos os que aqui habitam/desde épocas mais antigas,/velhos, moças, raparigas,/submissos aos que lhes ditam/nossas palavras amigas./Vou contar todos seus vícios, /[...]" (ANCHIETA, 2012, p.19. Grifo meu). 
Ao por tal discurso na boca do demônio-índio, Anchieta já antecipa sua posição (e da Igreja) sobre a cultura autóctone, que independente de ser um elo identitário, tais práticas devem ser combatidas, afinal, os índios só serão salvos caso 'deixem de ser' índios. Essa é a ideia central de todo segundo ato: a orbis christianus entra em choque com a visão cosmogônica dos indígenas, objetivando provocar identificação e rejeição aos hábitos e costumes dos não catequizados e inimigos da coroa portuguesa.

É clara a oposição dos demonizados contra os missionários e seu projeto civilizador: "Vêm os tais padres agora/ com regras fora de hora/ prá que duvidem de mim./ Lei de Deus que não vigora" (ANCHIETA, 2012 , p.6). Ainda, a fala de Aimberê traz a mensagem que as regras civilizatórias trazidas pelos religiosos são regras divinas. Quem as cumpre está com Deus, quem as desobedece está contra Ele.

Na mentalidade religiosa, Anchieta faz uma analogia entre a dança, o folgar e o beber à selvageria, logo, à animalização:

O estatuto selvagem. Guiaxará, [...] identifica-se com boicininga (cascavel), jaguar, andirá-guaçu (morcego); Aimberê confunde-se com jiboia, taguató (gavião), tamanduá. S. Sebastião e o Anjo chamam Saravaia de rata, gambá, morcego, larva, cururu( sapo) e sanguessuga. Suas ações são estereótipos medievais de demônios metamorfoseados em animais. (BONNICI, 2000, p.65)

De acordo com Certaeu (1982) a produção de sujeito visa a produção de nomes, que só adquirem sentidos quando são excessivamente adjetivadas e predicadas (p.259). Desta forma, não é somente a zoomorfização que os constrói, os índios inimigos são adjetivados de forma negativa. Guaixará, por exemplo, é nomeado como embriagado, antropófago e matador (ANCHIETA, 2012, p.15). O vocabulário anchietano estrutura-se para dar significado ao processo de demonização. Contudo, a estrutura da peça também (re)cria novos significados, quando expõe o lirismo e a superioridade espiritual do europeu na língua vernácula dos religiosos em cena musicadas em oposição à língua nativa em cenas com os demônios e de conflitos: "A língua tupi, portanto, está a serviço da maldade, da raiva, da perversão e do castigo, em contraste com o conteúdo cristão e singelo transmitido em língua castelhana" (BONNICI, 2000, p.64). 
A demonização sempre está oposta a divinização e civilidade cristã -europeia no Auto de S. Lourenço. A única saída para essa bipolarização, que levaria uns ao Paraíso e outros ao Inferno seria homogeneiza-los, isto é, cristianizar todos, sem exceção, pois nas falas de S. Lourenço apenas a confissão e a comunhão católica pode curar e depurar a alma dos índios da perdição. (ANCHIETA, 2012, p.21). Tal mensagem salvífica é dada por "Bastião, de flechas crivado" e "O file Capitão de Deus" (ANCHIETA, 2012, p10), respectivamente, S. Sebastião e S. Lourenço.

Assim, a punição dos três diabos no inferno - "Guaixará seja queimado,/Aimbirê vá para o exílio,/Saravaia condenado!” (ANCHIETA, 2012, p.30) - representa a queima e aniquilação de todo antigo costume dos índios, a filiação política dos tamoios bem como a padronização da cultura cristã.

Finalmente, o outro demoníaco foi sepultado no inferno, cujo fogo acultural fora aceso na chegada dos missionários às Américas.

Ao analisarmos o outro em textos pós-coloniais, sempre esperamos um embate ou uma polarização frente ao Outro colonizador. Nas literaturas catequéticas observamos inúmeras estratégias do colonizador a fim de alicerçar sua considerada cultura superior, sendo a conversão e demonização as mais comuns.

No texto do missionário peruano Antonio Ruiz de Montoya, $A$ Conquista espiritual (1639) observa-se a incisiva resistência dos pajés/ caciques Neçu, Taubici, Guirabera, Maracanã e Artiguaye contra a dominação espiritual cristã. Já em Na festa de S. Lourenço (1587), do jesuíta José de Anchieta, o teatro é pano de fundo da apresentação dos índios rebeldes Guaixará ,Aimbirê e Saravaia. Em ambos os textos os jesuítas e os conversos fazem parte de um propósito salvífico, que visa à salvação da alma, bem como a civilidade dos autóctones. Entretanto, nos dois textos é clara a construção diabólica daqueles que não aceitam esse propósito eurocêntrico, processo chamado demonização.

Por fim, as práticas culturais indígenas, tanto dos guaranis, como a dos tupis e demais etnias, como a dança, folguedos, adornos, o fumo, a feitiçaria, a poligamia, e glutonia são lidas pela religião cristã como práticas pecaminosas, que somente a conversão e aceitação da fé católica podem apagar. Assim, o ambiente colonial, frequentemente, a aculturação torna-se o fenômeno resultante da prática 'pedagógica' que é o demonizar. 


\section{Bibliografia}

ANCHIETA, Pe. J. de. O auto de São Lourenço. (versão on-line).

Disponível em: http://virtualbooks.terra.com.br/freebook/port/download/ Auto_de_Sao_Lourenco.pdf. Acesso em 03 jun. 2012.

BHАВНА. H. O local da Cultura. Belo Horizonte, Humanitas: Ed. UFMG, 2005.

BOGONI, R. Resistência do sujeito colonial na região guaranitica do Paraná, em Conquista Espiritual (1639), de Antonio Ruiz de Montoya. In: BONNICI,

T. Resistência e intervenção nas literaturas pós-coloniais. Maringá: EDUEM, 2009. P.

BRAGA-PINTO, C. As promessas da história: discursos proféticos e assimilação no Brasil colonial (1500-1700). São Paulo: EDUSP, 2003.

COSTA, P. E. da S. Do sensível ao inteligível - $\mathbf{O}$ auto de $\mathbf{S}$.

Lourenço. Dissertação de Mestrado, UFPB, João Pessoa, 2007, 201p.

FAUSTO, C. Se Deus fosse jaguar: canibalismo e cristianismo entre os Guaranis (séculos XVI-XX). In: Mana, Rio de Janeiro, v. 11, n. 2, 2005, p. 385-418.

GREENBLATT, S. Possessões Maravilhosas: o deslumbramento do Novo Mundo. São Paulo: EDUSP, 1996.

LUFT, C. P. Minidicionário Luft. 20ª Ed. $6^{\text {a }}$ impressão. São Paulo: Ática, 2001.

MACHADO, G. J. C. A Conversão Religiosa. nov/94. Disponível em: http:// www.urisan.tche.br/ cienciadareligiao/artigos/artconversao.htm. Acesso em 06 out. 2011 [1994].

MARTINS, M. de L. de P. Auto representado na festa de São Lourenço, de José de Anchieta. Museu Paulista, boletim I, São Paulo, ano I, documentação linguística 1, pp138. [peça triligue do séc. XVI, transcrita, comentada e traduzida do tupi por Maria de Lurdes de Paula Martins], 1948.

MELLO \& SOUZA, L. Inferno atlântico. São Paulo: Companhia das Letras, 1993. 
MENGET, P. A política do espirito. In: NOVAES, A.(org) A Outra Margem do Ocidente. São Paulo: cia. da letras, p.p. 167-180. 1999.

MONTOYA, A. R. de. Conquista espiritual feita pelos religiosos da Companhia de Jesus nas Províncias do Paraguai, Paraná, Uruguai e Tape (1639). $2^{\mathrm{a}}$ ed. Brasileira. Porto Alegre: Martins Livreiro Editor, 1997. . Conquista espiritual. Porto Alegre: Martins Livreiro,

1985.

Conquista espiritual hecha por los religiosos de la Compañía de Jesús em las provincias del Paraguay, Paraná, Uruguay y Tape. Bilbao: Imprenta del Corazon de Jesús, 1892.

MOUTINHO, M. Pe. Bibliografia para o IV centenário da morte do beato José de Anchieta [ 1597-1997], v.1. Ed. Loyolas: São Paulo, 1999.

PARADISO, S. R. A Possessão como ambivalência colonial. Identidade e resistência na religiosidade africana em $O$ outro pé da sereia. In: Nau Literária (UFRGS), 2011.

PARADISO, S.R; BONNICI, T. Objetification and Othering in Is there nowhere else where we can meet? (1951), by Nadine Gordimer In: Acta Scintiarum

Language and Culture, v. 34, n. 2 (on line), 2012.

VIEIRA, C. M. N.; SOUZA, N. M. O enfrentamento entre indígenas e o colonialismo luso-espanhol no Itatim $(\mathbf{1 6 3 0 - 1 6 5 9 )}$ in: Anais do XVII Encontro Regional de História - O lugar da História. ANPUH/SPUNICAMP. Campinas, 6 a 10 de setembro de 2004. Disponível em http://www.anpuhsp. org.br/sp/downloads/CD\%20XVII/Paineis/Carlos\%20 Magno\%20Naglis\%20 Vieira.pdf Acesso em 03 jun. 2012[2004].

\section{Imagem}

Disponível em http://t3.gstatic.com/images?q=tbn:ANd9GcTSHP6GEz4xlYfqKJE2-MO5VRoAsqgyi4NPt-YxO8Fp3P7Z254U. Consultado em $07 / 10 / 2012$ 